\title{
Meditation, Idealism and Materiality: Vivid Visualization in the Buddhist 'Qizil Yoga Manual' and the Context of Caves
}

\author{
Karen O'Brien-Kop $^{1}$
}

Accepted: 9 November 2021 / Published online: 25 February 2022

(C) The Author(s) 2022

\begin{abstract}
This paper examines the topic of Yogācāra idealism through a little studied Buddhist meditation manual, the so-called 'Yogalehrbuch' or 'Qizil Yoga Manual', a primarily Buddhist Sarvāstivāda Abhidharma text with Mahāyāna Yogācāra strands. What does this unique Central Asian text say about Buddhist meditation practices called yogācāra or yoga? It centres on methods of vivid visualization that are somewhat specific to the Central Asian region of Kucha on the Silk Road. To understand the Manual's practice and definition of yogic meditation, this paper considers how some of the hyper-real visualizations in the dhâtuprayoga section relate the mind to reality and whether Yogācāra meditation can be said to propose idealism as a metaphysical theory about the nature of reality. The paper also asks whether neurocognitive research insights can be useful in understanding what some regard as a 'hallucination-like' quality of some visualizations, which destabilise distinctions between appearances and reality. Furthermore, it argues that analyzing the materiality of meditation, particularly the environment of the cave, helps us to better understand the text's techniques of yogic visualization. The paper concludes that the 'Qizil Yoga Manual' facilitates soteriological idealism and suggests that factoring in the material contexts of meditation is useful, both in deciphering the text's meditation methods and in discussing the metaphysical theory of idealism.
\end{abstract}

Keywords Yoga · Yogācāra · Yogalehrbuch · Idealism · Qizil Yoga Manual · Buddhist visualization - Buddhist yoga $\cdot$ Material religion · Cave meditation · Central Asian Buddhism

Karen O’Brien-Kop

Karen.obrien-kop@roehampton.ac.uk

1 Lecturer in Asian Religions and Ethics, University of Roehampton, London, UK 


\section{Introduction}

Sustained scholarly debates on Buddhist Yogācāra philosophy as 'idealist' have continued for some decades, ${ }^{1}$ probing the question of whether the doctrine of cittamatra (mind-only) ${ }^{2}$ indicates a metaphysical theory in which the nature of reality is dependent, to some degree, on the mind. ${ }^{3}$ This paper approaches the topic of Yogācāra idealism from the perspective of the Central Asian 'Yoga Manual' ('Yogalehrbuch') from Qizil, a fragmentary Buddhist meditation text from c. $4^{\text {th }}-6^{\text {th }}$ century CE (Schlingloff, 2006). ${ }^{4}$ The term 'cittamätra' is not used in the 'Qizil Yoga Manual', which is more practically than philosophically oriented. Nonetheless I will argue that a consideration of this text's meditation method can contribute to the discussion on metaphysical idealism. ${ }^{5}$ The manual describes meditative practices sometimes called 'yoga', refers to a practitioner as a yogācāra or yogin and references a prior yogaśāstra. ${ }^{6}$ It also bears the imprint of several early Yogācāra meditation manuals from South Asia. I hope to demonstrate that the material context with which this text is associated, the environment of caves, helps us to understand not only the reasons why Yogācāra meditation might be interpreted as idealist, but

\footnotetext{
${ }^{1}$ There is a wide range of divergent and nuanced views on this issue. See, for example, arguing broadly or more sympathetically towards an interpretation of idealism: Rotem (1993), Garfield (2002), Gold (2007, 2015), Bayer (2019). And against: Willis (1979), Kochumutton (1982), Anacker (1984), Lusthaus (2002), Dunne (2004). I will not engage in-depth with these specific debates here, as I seek to ask what can be gained by considering the contextual factors of meditation practice, as well as interdisciplinary insights from cognitive science and material culture.
}

${ }^{2}$ This Yogācăra theory was known by different names: not only cittamätratā (the doctrine that there is nothing but mind) but also vijñanavāda (consciousness doctrine) and vijñaptimatratā (the doctrine that there is nothing but representation). The first exposition of the doctrine of mind-only or representation-only is commonly traced to Vasubandhu's works: Vimśatikāvijñaptimātratāsiddhi, Trimśikāuijñaptimātratā [siddhi]kārikā and Trisvabhāvanirdeśa. However, Asanga also uses the term cittamätra in association with the theory of eight consciousnesses set forth in the Viniścayasamgrahaṇ̄ portion of the Yogācārabhümiśāstra, as well as in his other works, the Mahāyānasamgraha and Mahāyānasūtrālañkāra. Indeed, the earliest use of the stock phrase associated with this doctrine - 'these three realms are nothing but mind' (cittamätram idam yad idam traidhätukam) - occurs in a Buddhist Sanskrit text no longer extant but which was translated into Chinese in $179 \mathrm{CE}$, the * Bhadrapālasūtra (Schmithausen 1973, pp. 246-247). The same phrase subsequently appeared in both the Daśabhümikasūtra (Rahder 1926, pp. 49, 74) and the Samdhinirmocanasūtra (Lamotte 1935, pp. 90-91).

${ }^{3}$ Although discussions on idealism often start with western definitions such as Berkeley's subjective idealism, this author prefers to stay focused on South Asian philosophical reference points and assumes a useful working equivalence between the terms 'idealism' and 'cittamātra'.

${ }^{4}$ Buescher dates to the c. $5^{\text {th }}$ century (Buescher 2008).

5 Trivedi outlines a useful and clear distinction between metaphysical idealism (which encompasses ontological idealism), epistemic or epistemological idealism, and absolute or transcendent idealism (Trivedi 2005, p. 232). Metaphysical idealism is the view that external objects exist in a mind-dependent way; epistemic idealism claims that our knowledge of the world is always conditioned by our own conceptions and limitations; absolute idealism is the claim that there is a transcendent mind or reality that contains both subject and object. Here I am concerned primarily with metaphysical, specifically ontological, idealism and also to a lesser degree with absolute idealism with regards to non-dualism.

${ }^{6}$ See discussions of yoga (YL 147V4); yogaśāstra (YL 128R3); yogācāra (YL 127V3; 128R2; 128V5; 139R3; 165R2; $165 \mathrm{~V} 1$ ); yogin (YL 130R5; 144R6; 144V5; 148V4; 160V2). All YL references are from Schlingloff 2006. For a discussion of the relationship of early Yogācāra to yoga, see O'Brien-Kop (2021, pp. 75-112). 
also how this method is served by a soteriological idealism that is logically entailed in the meditation practice itself. I will also employ selected insights from neuroscientific research on visual cognition to analyse some stages of the visualization methods described in the 'Qizil Yoga Manual'. ${ }^{7}$ This paper posits that the 'Qizil Yoga Manual' offers us a fresh route to approach the philosophical debates on Yogācāra so that subjective idealism can be reframed by considering embodied and material meditation practices in this early Buddhist text. Indeed, the debate is enhanced by considering not only ontological and epistemological definitions of idealism, but also the more pragmatic and temporary nature of what may be termed 'soteriological idealism'.

\section{Background on the 'Yogalehrbuch' or 'Qizil Yoga Manual'}

From 1903 to 1906 there was a find of manuscript fragments in Qizil in the Kucha region and in Shorchuk (in modern China) by the third German expedition to Turfan. Qizil is 42 miles $(67 \mathrm{~km})$ to the west of Kucha (an oasis kingdom) and was an important hub on the northern Silk Road and a thriving centre of Buddhism from the 3rd to 8th centuries CE. It was also the site of a Buddhist cave complex, the early construction phase of which is dated to the lifetime of Kumārajīva, 344-423 CE (Hansen, 2012, p. 65), and which contains images of objects and figures in meditation. One of the fragmentary Sanskrit texts found at Qizil (and written in the Brāhmī script $)^{8}$ was partially reconstructed and translated into German by Schlingloff in 1964. Since the title of the text was not apparent from the surviving fragments, Schlingloff named the text 'Yogalehrbuch' ('Yoga Manual' in German). He had to piece together his edition from an array of manuscript fragments, and the fragility and dispersion of the surviving fragments partly accounts for the relative lack of scholarship on this text. ${ }^{9}$ This 'yoga manual' reflects both Buddhist Sarvāstivāda and early Yogācāra meditation, ${ }^{10}$ and most likely represents the transmission of Buddhist practices from Kashmir and Gandhara to the Kucha region.

Schlingloff managed to recover an estimated $42 \%$ of the original (Schlingloff, 2006, p. 12), and additional fragments have been added during the past half century. The manuscript was birchbark (Hartmann, 2006, p. 310), unusual for Central Asian

\footnotetext{
7 I will refer to the text using the label 'Qizil Yoga Manual' and retain 'Yogalehrbuch' when citing secondary scholarship that uses this title, especially Schlingloff's.

8 The 'Yoga Manual' is written in North Turkestan Brāhmī, Type A, a script developed by the Tocharians from Northwestern Indian scripts (Howard and Vignato 2015, p. 155). The related Pelliot fragments are written in North Turkestan Brāhmī Type A-B (Yamabe 2006, p. 238).

9 This is, however, about to change since a project funded by the Robert Ho Foundation is currently producing a new English translation of the 'Yogalehrbuch' https:/www.acls.org/Fellows-and-Research/ Recent-Awardees/The-Robert-H-N-Ho-Family-Foundation-Grants-for-Critical-Editions-and-ScholarlyTranslations/?year=2018 [last accessed 6.05.21]

10 On the entanglement between early Yogācāra and Sarvāstivāda see Deleanu 2006; Stuart 2015; O’Brien-Kop 2020 and 2021.
} 
manuscripts, which were more typically written on paper as per the Chinese tradition (Hartmann, 2004). Subsequently, Schlingloff and others located a small number of fragments from one or more other paper copies of the text (or closely related texts) from the Kucha region (Hartmann 2006, pp. 310, 311). Schlingloff explains that the manual resembled the Central Asian paper manuscripts in scope, form and script, but, being written on birchbark, was most likely imported from North India (Schlingloff, 1964, p. 146; Hartmann, 2006, p. 310). ${ }^{11}$ The existence of multiple copies indicates that, at least in Kucha, the text had a circulation (Hartmann, 2006, p. 312) and we could even speculate that it was an important text in this region. In fact, the 'Qizil Yoga Manual' is part of a longer manuscript, numbering some 170 pages, that appears to have contained two separate works on yoga bundled together (Schlingloff, 1964, p. 146). The first text, around 114 pages in length, was, according to the colophon, called the Yogavidhi, and contained sütras and a commentary thereon (Schlingloff, 2006, p. 12) dedicated to the topic of ' $y o g(\bar{a}) b h y \bar{a} s(a)$ ' or the practice of yoga (YV 1R1; Schlingloff, 1964, p. 148). ${ }^{12}$

The connections of the 'Qizil Yoga Manual' to South Asian Yogācāra texts have been noted. As Schlingloff observed, the primary orientation of the text is Sarvāstivāda Abhidharma, but it also converges with the Mahāyāna bodhisattva ideal, such as a representation of nirvāna as a city which closely echoes an image in the Mahāparinirvānasūtra (YL 169-172). ${ }^{13}$ In structure, the Qizil fragment is similar to the Dharmatrātadhyānasūtra (Damoduoluo chan jing aka Buddhasena's Yogācārabhūmi), thought to based on Saṅgharakșa's *Yogācārabhūmi (Demiéville, 1951). As Davidson has shown, the content of the Qizil fragment also maps to Asañga's Bodhisattvabhūmi (Davidson, 2010, p. 189), ${ }^{14}$ and Bretfeld has suggested a direct connection between the 'Qizil Yoga Manual' and Yogācāra's epistemic idealism (Bretfeld, 2003, p. 200). In art history scholarship, since Qizil Cave 83 (circa 450CE) portrays Maitreya and other bodhisattvas performing miracles after his death (Tremblay 2007, p. 104), Tremblay suggests that Mahāyāna influences were strong in Qizil until the 6th century when beliefs waned, so that '[b]y the time of the Chinese pilgrim Xuanzang (602-664), Kucha seems to have become a stronghold of the (Mūla)Sarvāstivādins' (Tremblay 2007, p. 104). The text, then, shares structure and content with both early Yogācāra and Sarvāstivāda meditation texts and perhaps some hints of later Yogācāra epistemology. ${ }^{15}$

\footnotetext{
11 Errors suggest that the scribe did not understand the text from which it was copied, probably the Indic Gupta script, Gupta scripts being common to Afghanistan (Schlingloff 1964, p. 146; Hartmann 2004).

12 Schlingloff suggests that the Yogavidhi contains sütras in the style of the Yogasütra of Patañjali (Schlingloff 1964, p. 146), although the relevance of this comparision is not immediately apparent.

13 This point is discussed by Hartmann (2006, p. 311). See also Seyfort Ruegg on the Mahāyāna influences in the 'Yogalehrbuch' (Seyfort Ruegg 1967).

14 Davidson analyses the pattern of the abhișeka rite, almost as a structuring principle for the various meditations in the Qizil fragment, noting its similarity to accounts in the Bodhisattvabhümi, Daśabhūmikasūtra and Lañkāvatārasūtra (Davidson 2010).

15 Deleanu employs a distinction between yogācāra (early and ascetic) and Yogācāra (later and philosophical) (Deleanu 2006). I follow Deleanu's convention elsewhere, but in this paper use only Yogācāra since we are discussing a specific philosophical doctrine.
} 
The Qizil manual foregrounds visual meditative exercises carried out by an adept called a yogin or yogācāra, ${ }^{16}$ and the emphasis on visualization affirms Buescher's observation that there was a distinctive visionary quality to the practices called Yogācāra that developed in north-west India (e.g. greater Kashmir, Gandhara) (Buescher, 2008). ${ }^{17}$ The contents of the 'Qizil Yoga Manual' are as follows (Schlingloff, 1964):

1. aśubhaprayoga (exercises on the repulsive)

2. ānāpānasmrtibhāvanā (cultivation of mindfulness of breathing)

3. dhätuprayoga (exercises on the elements)

4. skandhaparīkșa (examination of the aggregates)

5. āyatanaparīkșā (examination of the sense bases)

6. pratītyasamutpādaparīkșā (examination of dependent co-arising)

7. maitrī (friendliness)

8. karuṇā (compassion)

9. muditā (joy)

10. upekșā (equanimity)

11. anusmṛti (recollection; buddhānusmrtit, ${ }^{18}$ dharmānusmṛti, saṃhānusmṛti, śīlānusmṛti, devatānusmrti)

On the surface, each of the 11 sections represents a standard list of Buddhist Sarvāstivāda meditation topics, yet, as Yamabe has suggested, the Kucha people seem to have exercised 'a significant degree of originality in regard to some details of this text' (Yamabe, 2006, p. 339). The claim for Central Asian innovation is made because the manual also describes vivid visualizations that seem extra-ordinary, paralogical, or bizarre.

\section{Meditative visualization, the body and soteriological idealism}

The 'Qizil Yoga Manual' contains vivid visualization techniques. I will focus here on some passages that describe dhâtuprayoga (exercises on the elements) in section three of the text.

At the outset of the section on dhātuprayoga, we are told:

Exactly so, for one who has completed the preparations beginning with moral conduct, [the yogin] focuses the mind between the nails of the big toes. ${ }^{19}$ Then

\footnotetext{
${ }^{16}$ I use the term yogācāra in this paper, as the 'Qizil Yoga Manual' does, to indicate meditation practitioner.

${ }^{17}$ For Schlingloff and Seyfort Ruegg these practices also point to Kashmir (Schlinghoff 1964, pp. 28-56; Seyfort Ruegg 1967, p. 157). For general discussions of visualization methods in early Buddhist texts, see, for example, Yamabe 1999a, pp. 125-184; McMahan 2002; and Greene 2016b.

18 Demiéville (1951) discusses buddhānusmrti as a characteristic feature of Yogācāra in relation to Sangharakșa and Buddhasena (both discussed above).

19 For a contemporaneous Buddhist visualization centred on the big toe, see Greene's discussion of the fifth-century Chinese manual Chan miyao jing (Secret Essential Methods of Meditation) in relation to white bone contemplation, a variation on aśubha practice in which the adept envisions his own mortal
} 
the nail interstice appears as if [it were] the mouth of a makara (water creature) ${ }^{20}$ into which the mind enters. ${ }^{21}$

tathaiva [ś]̄ī(lādikṛtaparikarmaṇaḥ p)[ā]dān(guṣ)[țha](na)khavivare cittopanibaddhah kāryah tato nakhavivaram makaramukham iva lakṣyate tena cittạ̣ praveśayati | (YL 128R4; Schlingloff, 2006, p. 86)

Other visualizations include the elements appearing from underneath the meditator's fingernails and suffusing the entire world before disappearing into the mouths of the makaras (water creatures) (YL 129R5); pearl necklaces emerging from the head of the meditator (YL 127R4-5); and visualizations of ghee and sesame oil filling up the body through a hole in the head (Pelliot Fragment 9.1R5; Yamabe, 2006, p. 331). ${ }^{22}$ In a meditation on the six elements, ${ }^{23}$ 'a sword comes out of the navel of the meditator and arranges the six parts of (?) the meditator's body separately on his skin' and with both hands the yogin examines the six elements one by one (YL 160V2; trs. Yamabe, 2006, p. 327). Elsewhere, 107 snakes in the body destroy 107 joints ${ }^{24}$ and moisten the tendons thus causing them to separate (Pelliot Fragment 9.1V d-g; Yamabe, 2006, pp. 332-334). 'So many snakes in so many joints... They burn the tendons. [The meditator] sees his own motionless body and all sentient beings as if falling down on the ground' (Pelliot Fragment 9.1V, f-g; trs. Yamabe, 2006, pp. 332-334). ${ }^{25}$

\section{Footnote 19 continued}

decay (Greene 2016b, pp. 317-318). The text instructs: 'First, fix your thoughts on the tip of your left big toe. Carefully contemplate one half of the toe and imagine a swelling. Carefully contemplate until this is very clear. Then, imagine a burst-open swelling. When you see the bone [beneath the burst-open swelling], make it extremely white and pure as if glowing with white light. Having seen these things, next contemplate the entire toe, stripping away the flesh, until you see the bone, making it extremely bright and clear, as if glowing with white light' (T613:15.243b28-c02; trs. Greene 2016b, p. 318).

20 The makara is a kind of mythical sea creature, fish, or crocodile with a range of meanings in Hinduism and Indian Buddhism.

21 Any unattributed translations are my own. The apparatus of Schlingloff's transliteration reflects the fragmentary nature of the manuscript.

22 The 'Pelliot Fragment' (see footnote 7 above) is most likely from another manuscript copy of the Qizil text or from a closely related version. The fragments were found by Hartmann in the Pelliot Collection in Paris and are thought to be from the court of Duldour-âqour in the Kucha area (Yamabe 2006, p. 328).

23 The six elements here are earth, water, fire and air, space (ākāśa) and consciousness (vijñanna).

24 For comparison, see Yamabe's discussion of the Ganmei sanfo hai jing (GSHJ) (Sūtra on the OceanLike Samādhi of the Visualization of the Buddha) and the Mahāyāna Mahāparinirvānasūtra (MMPS) in which the joint bones are significant: 'The joint bones of the Tathāgata are intertwined [like] coiled nāgas, without gap' (GSHJ T15: 648b28-29; trs. Yamabe 1999a, p. 250) and 'The joint bones of a bodhisattva of the tenth stage are intertwined [like] coiled nāgas' (MMPS T12: 429b16-19; trs. Yamabe 1999a, p. 242). See also in GSHJ: 'The bones of the elbow like the hairs of a nāga king are smoothly stuck together. [Nevertheless] its patterns are not destroyed. The tips of the joint bones are [intertwined like] coiled nāgas whose traces are invisible' (GSHJ T15: 648a4-c13; trs. Yamabe 1999a, p. 228). It is notable here that the joint bones are tightly interwoven by snakes and in the 'Qizil Yoga Manual' the loosening of these snakes is described.

25 The theme of pulling apart internal features of the body is noteworthy and has a biomedical tone. Such 'meditative dissection' is a common method of Buddhist visualization, from the Pāli canon to the Chinese Ganmei sanfo hai jing ('Sūtra on the Ocean-Like Samādhi of the Visualization of the Buddha') and other visualization sutras, such as Zhi chanbing miyao fa (Secret Essential Methods for Curing Meditation Sickness) which advocates visualization of the brain (Yamabe 1999a, p. 247). 


\section{The body and its material subjectivity}

These visualizations put the body at the centre of the picture: the images emanate not only from the yogin's mind but also from his body in intense visceral detail.

Thus people stream forth from the hairs on the head, pulsating and disintegrating.

[e](vạ̣) keśādipuru[șa](pra)vāhāḥ s[ph](a)raṇanirodhau ca | (YL 129V3; Schlingloff, 2006, p. 87)

And after each emanation, the visualizations are rhythmically absorbed back in to the body, often through the navel.

Then [the yogin] sees his own form sunken up to the navel. His location appears completely filled with trees ${ }^{26}$ at whose roots monks are seated practising the elemental exercises. From the interstices between their toenails, elements come forth, penetrate the whole world and are dissolved in these selfsame mouths of the makara (water creature). Just so [the yogin] sees the earth filled with persons [made] of the six elements. At times he sees the elements separated and at times united. Finally, everything is brought back into the navel. ${ }^{27}$

(tato) nābhiparyaṃta[n](imagnaṃ svam) [ā](śra)yam paśya(ti sthi)[t]iś ca v[ṛ]kṣaparipūrṇā dṛśya te tammmūlanișaṇnāa bhi[k](ṣ)[av]o

dhātuprayogaṃ bhā[va]y(aṃ)t(i) taṃnakhavivaranị̣ sṛtāś ca dhātavạ̣ kṛts[na]ṃ spharitvā parasparama[ka](ramukheșu teșv eva nirudhyaṃ te | evaṃ șaḍdhātaumayai)[ḥ p]u(ṛ)u[ș]aiḥ pṛ̣th]i(v)ī (pūrṇā)m (pa)śyati | kadā[c](i)d [dh]ātuṃ vyastāṃ paśyati kadācit samastāt | ante sarvaṃ nābhyāṃ nirudhyate (YL 129R5; Schlingloff, 2006, p. 89)

Certain apertures of the body, such as the navel, function as gateways (or interfaces) between the internally generated visualizations and an external, objective world. In this instance, an emanation from the body not only appears in the world but is said to change the world:

[The meditator] fills the whole world with the rays of blue and so forth of his own body. Then he goes out of the four seas. A stream of flowers that has come out of his navel goes to the four directions and falls on the four seas. Then the seas are filled with essence and the lotuses are brought hither (trs. Yamabe, 1999a, p. 346).

\footnotetext{
${ }^{26}$ See also this image of the tree in the Qizil manual: 'Then (a jewel tree) stands up from [the crystal man's] head filling the boundless realms of the world. On the leafy branches of that tree are seen buddhas preaching the dharma. Colourful rains of jewels, flowers and lotuses coming out of their [= the Buddhas'] mouths are scattered over the world. The hollow roots of the tree shining like vaidūrya are seen to be based on the golden disk together with (?) the soles of the feet of the yogācāra' (YL 127V2-3 in Schlingloff 2006, p. 79; trs. Yamabe 1999a, p. 323).

27 The importance of the navel as an interface is also evident in this passage: 'Then from the sunken point under (the middle of the brows), a stream of milk comes out; it breaks through the disk of the earth, assuages all the sufferings of sentient beings in the evil states, breaks through even (the disk of the wind [vāyumandala], comes back, enters) the navel, (comes out) of the head, goes (as far as) the akaniștha heaven, comes back, and enters the head, surrounded by gods belonging to [the realms of] desire, forms, and formlessness' (YL 132.3-6; trs. Yamabe 1999a, pp. 314-315).
} 
n̄̄lā[dya]bhiś ca sv[ā]śsrayaprabhābhị̣ kṛt[s](n)ạ̣ (lokam āpūrayati | caturbhya)[ś ca sa]mudrebhya ut[t]arati | [n]ābhyāś câsya (pu)șpapravāho niḥsṛtaḥ caturdhā [gaccha]ti | samudreșu caturṣu patati | tata samudra rasaị pūryaṃte | pa[d]māni copa(nīyaṃte | (YL 131V2-3; Schlingloff, 2006, p. 92)

From these passages alone, we can assert that the meditating subject represents a kind of subjective idealism, in that the whole world seems to be generated by the mind of the meditating individual. Yet these visualizations are not simply one-way projections onto an external canvas of objective reality; they are also transactional processes that alter the subject. The subjectivity that is suggested by these images is not only mental but is acutely embodied in a material sense ${ }^{28}$ :

[the meditator] sees [his own] body filled with winds. [He sees] the winds entering through all the [body] openings...all...[sees] himself sunk in the lake of oil, and that oil has entered [him] through all of the [body] openings (trs. Yamabe, 1999a, p. 349).

tivat pūrṇam āśrayaṃ vāyubhị paśyati | sarvasrotobhir vāyun praviśato...[s]i [sa]rvaṃ [v]ā si...(taila)hradanimagnaṃ câtmānaṃ sarvasrotobhis tailena praviśatā iti sarvak[ā](yapratisaṃvedanāyām)\| (YL 118V2-4; Schlingloff, 2006, p. 69)

Many of the images in dhatuprayoga are disturbing or exciting, such as the figure of a man arising and holding a knife (YL 130V6; Schlingloff, 2006, p. 90), ${ }^{29}$ or the sequence in which a 'a black and heated boil' grows 'in the middle of the brows' and from which a woman emerges (YL 135.10-136.2; trs. Yamabe, 1999a, p. 65). Again, such graphic images highlight the emphasis on visceral embodiment as a key facet of subjectivity. During such meditative visualization, all objects of perception are minddependent, and yet what is often the focus of perception is one's own body rather than external objects.

\section{Āśraya: generation and dissolution of one's own form}

The body of the meditator is most acutely represented by the term äśraya. In each elemental visualization, the form of the yogin, or the āsraya (which Schlingloff translates as the gestalt and sometimes as Körper, or body) is repeatedly visualized with the refrain, svam āśrayam paśyati (Pelliot Fragment 9.1R1; Yamabe, 2006, p. 329), 'one sees one's own body (or form)'. This personal form appears and disappears in many sequences, so that the self is visualized, instantiated and dissolved at will: cchidram śunyam àt $[m] \bar{a} t(m)$ ìyavirahi(tam (YL 130R1; Schlingloff, 2006, p. 91), 'torn, empty, abandoned of self and one's own self'. How are we to understand áśraya technically? One standard definition of āśraya in Buddhism is

\footnotetext{
${ }^{28}$ Every effort will be made to maintain some clarity between 'matter' as a broader principle/phenomenon within which specific 'substances' occur, such as 'water', 'gold' or 'soil' or, indeed, 'mind'.

29 'Then [for the yogin], all preparations accomplished, due to being established in concentration, there arises a person with a knife'. punah parik(r)takarmaṇo 'vasthitasamādheh saśastrah puru(șa utpadyat)e.
} 
as the five organs of sense combined with manas (mind), i.e. the body, but, more specifically, the āśraya in Sarvāstivāda discourse can refer to the mental substratum. ${ }^{30}$ Seyfort Ruegg understands the áśraya as a "psychosomatic "Form", which is comprised of the six elements (Seyfort Ruegg, 1967, p. 162), ${ }^{31}$ hence the reference to cutting the áśraya into six pieces (YL 160V2; quoted above) is the separating of those elements. ${ }^{32}$

Beyond generation, the dissolution of the äsraya is equally important; the doctrinal point of this dhätuprayoga is to know the self as non-essential, interdependently arising and constituted through the elements. In this doctrinal sense, the yoga can be said to be a practice of ontological idealism, since the goal of these meditations is to demonstrate the unreality of the apparently fixed and permanent empirical world, subjective or objective (which can be created and dissolved at will by the yogācāra). There is a recurring pattern of seeing an entity arise, followed by its disappearance or dissolution (layanam; YL 130V3), concordant with the Buddhist dharma theory of a world in flux. What is the role of the body here? If we accept that the mind is not separate from body, ${ }^{33}$ then the experience of generating and seeing the images (especially the disturbing images) produces biophysical responses that alter the very materiality of the mind-body complex. ${ }^{34}$ Hence one has not only generated a new non-material (imagistic) reality through one's mind that dissolves the standard conceptions of self, but one has also altered one's embodied and material self to produce an 'ontological displacement'. However, this displacement is temporary because each visualization completes with dissolution of the form, and each meditation sequence comes to an end. What I want to suggest then is that meditative visualization is a practice of subjective idealism, but is qualified by the following: (a) it extends only as long as the meditation session and

\footnotetext{
${ }^{30}$ For a further discussion of āśraya in the Abhidharmakośabhāṣya and the Pātañjalayogaśāstra, see O’Brien-Kop 2018. For an analysis of nine distinct meanings of äśraya, see Nagao 1991, p. 75.

31 Another clue is that the áśraya is to be made Brahman-like (brahmasadría) (YL 153 R5). Ruegg discusses this point, noting that the compounds buddhäśraya and bhagavadāśraya suggest that there are other transcendent meanings of áśraya in addition to the 'psychosomatic' (Seyfort Ruegg 1967, p. 164). Seyfort Ruegg traces this process as familiar in early canonical Buddhist texts in the context of $k \bar{a} y \bar{a}$ smrtyupasthāna and as foreshadowing the Tibetan $g$ Cod process of carving up the skandhas (Seyfort Ruegg 1967, p. 162).

32 Compare this practice of ásraya with the visualization of the body as studied by Yamabe in his analysis of the Chinese meditation manual GSHJ and its related images of consecration (abhiseka) and medicine, which also suggest a material and transactional quality to meditation: "the meditator should create the image of medicine in his mind. First he visualizes the body. Having made the image of the body, he opens the head and makes it empty. Then he makes the images of a Brahmā king, Indra, and various deities holding jewel jars. [The meditator further] visualizes that they are holding and sprinkling medicine. When the medicine enters the head it pervades the whole body and the vessels' (GSHJ T15: 664c9-11; trs. Yamabe 1999b, p. 5).

33 Conceptual metaphor theory argues that there are no concepts apart from those generated by sensorimotor experience, i.e. no concepts without psycho-physical experience to generate them (O'Brien-Kop 2021, especially Chapter One).

34 We have noted that dhātuprayoga consists of the four mahābhütas (gross elements/substances) plus space and consciousness.
} 
(b) it in no way posits a mind-only subjectivity that excludes the body or is detached from material experience. ${ }^{35}$

\section{Soteriological idealism}

In the Qizil manual, meditation may be understood as a strategy of temporary idealism (in this instance a mind-generated corporeal-material experience) using specific conditions for meditative cultivation. Hence, vivid visualization in meditation generates levels of ontological displacement to create non-ordinary (or alienated) states of awareness that have soteriological function. This argument requires going beyond an understanding of visualization as seeing mental imagery with the mind's eye, to argue for a material experience of envisioned phenomena in the body itself. ${ }^{36}$ In this understanding of idealism, visualizations do not construct objective reality, but by altering subjective reality (i.e. the domain of the mentalcorporeal) there is a temporary suspension or even reconfiguration of the objective, since the objective (in meditation) is mediated by the subjective (the self). ${ }^{37}$

Although the depiction of Yogācāra as idealist is contested, I suggest that a qualified understanding of its 'mind-only' (cittamātra) position as idealist is fitting in the case of the Qizil manual. Dating to the same period as the 'Qizil Yoga Manual', the Pātañjalayogaśāstra critiques the Buddhist cittamātra proponents as those who deny the existence of an objective world by saying that it is only an imagined construct (parikalpanā) (PYŚ 4.14) - a broad definition of metaphysical or ontological idealism. Yet in the case of the 'Qizil Yoga Manual' I argue that the idealism is more distinctly soteriological; if we take Ratié's definition of the ultimate goal of Vijñānavāda idealism as to 'awaken from the ordinary constructed world' (Ratié, 2010, p. 475), then this too applies to the practical goal of the 'Qizil Yoga

\footnotetext{
35 One counterargument to idealism is that some of these visualizations are explicitly framed as symbols. For example, in the dhātuprayoga section we are told in a sequence of elemental visualizations: garudamukham utpadyate ('the mouth/beak of an eagle arises') (garudamukham utpadyate). This image is followed by that of a firefly glow-worm: 'That having dissolved, the [yogin] sees the sign of consciousness like a firefly glowworm pulsating, blazing,' tadaṃtargatạ̣ khadyotakrimim iva spandamānaṃ jvalitam vijñānaimi(tta)[ṃ] (paś)y(at)i (YL 130V3; Schlingloff 2006, p. 90). Schlingloff translates 'nimitta' as symbol rather than sign/ indication. In the symbolic realm a symbol stands in for something else, whereas a sign indicates (or affirms) that a change in the state of reality has occurred by the appearance of a specific form. Seyfort Ruegg argues that the visual imagery is not meaningful in and of itself but forms a kind of visual syntax or meta-language for deeper meanings - hence, he argues, the images are not signs (indications) but symbols (representations). 'One of the remarkable features of this Yoga is that each meditation is symbolized by, or as it were concretely embodied in, a vision which is its nimitta or adhipatirūpa' (Seyfort Ruegg 1965, p. 165). Ruegg understands certain images of figures to be symbolic, 'representing an attainment' (Seyfort Ruegg 1965, p. 165). Such visual tokens include the recurrent figure of the child (bäladāraka), which symbolizes the mind (citta) and consciousness (vijñāna). $\bar{A} k \bar{a} s \dot{a}$ is represented by a conch shell, and mindfulness by various images of oil (Seyfort Ruegg 1965, p. 165).

${ }^{36}$ Envisioning alters sensory-motor experience itself and hence our corporeal interface with objective reality. And if the interface itself is altered, then this is enough to change apprehension of objective reality, since there is no pure apprehension of external phenomena without this sensory-corporeal interface.

37 Indeed the centrality of the subject is hinted at by Davidson, who argues for an 'internalisation' of ritual (in particular abhișeka) in the 'Qizil Yoga Manual' in comparison to Indian sources (Davidson 2010). Similarly, Seyfort Ruegg asserts that the meditative visualizations are not 'ecstatic' but 'enstatic' (Seyfort Ruegg 1967, p. 165) and that each meditation is 'concretely embodied' (Seyfort Ruegg 1967, p. 165).
} 
Manual'. It is the 'being' of the meditator that is under scrutiny, rather than the external world itself. This does not entail that consciousness generates matter outside of the body; rather, each time one meditates by visualising áśraya, one experiences an ontological displacement, and over a long period of practice these accrued changes alter the practitioner's mental and bodily reality altogether.

\section{Visualization, Hallucination, Reality Processing}

Let us now consider the peculiarly vivid quality of some visualizations in the Qizil Manual and what this might add to debates about idealism. Greene provides an expert genealogy of the term 'visualization', its Eurocentric episteme, and its misuse as a catch-all term for a range of Buddhist meditative practices, by which it is applied to recollection, 'seeing' the Buddha, tantric imagination and so forth (Greene, 2016 b). He also states that visualization is 'not hallucinating (or having a vision), since it is a controlled, self-generated, "active" state' (Greene, 2016b, p. 312; author's emphasis). ${ }^{38}$ However, on this point I disagree with Greene, because his non-technical definition of hallucination (which is arguably not the same as having 'a vision') excludes a cognitive understanding of hallucination in which it may, indeed, be a 'controlled, self-generated, active state'. Both terms are, of course, semantically and culturally charged: 'hallucination' with specific biomedical and pathological meanings, and having 'a vision' with connotations of religious mysticism and ecstasy. Nonetheless, Greene's overall conclusion on the specific semantic properties of visualization is entirely convincing:

"Visualization" is thus delicately contrasted with a number of potentially similar terms (imagining, seeing, hallucinating, having a vision), and, indeed, it is precisely in such contrasts that the meaning of the word is to be found (Greene, 2016b, p. 312).

Ultimately, for Greene, the specific quality of visualization entails a 'distinctive, photographic-like phenomenology' and 'clarity' that is more than a vague imagining (Greene, 2016b, p. 320). One might ask: what is the role of vividness in the images of the Qizil manual? Is it an aide-mémoire in the way that epic oral narrative employs vivid details to ensure the mnemonic reproduction of textual elements? Is the very vividness of the images designed to connect them associatively in sequence, or to enhance recollection of a previous image (from a prior meditation)? Most likely these functions are embedded, but the vividness in its apparent 'hyper-reality' (i.e. not being naturalistic) also brings out cognitive disruption during meditation, in terms of knowing what is real and what is not real. I argue that disruption is a key and productive function of this technique.

\footnotetext{
${ }^{38}$ Greene notes the pathological associations of the term 'hallucination' in comparison to the more psychological 'visualization' from the $19^{\text {th }}$ century up to the present day: 'The ability of "visualization" to make what might otherwise be dismissed as hallucination, fantasy or hypnotism seem interesting or worthwhile' (Greene 2016b, p. 326). 'Visualization' has a respectability that ensures the Buddhist practices do not seem too 'outlandish' to contemporary western epistemology (Greene 2016b, p. 328).
} 
Here, I propose that a cognitive account of visual hallucination may provide some useful insights for examining meditative visualization in the Qizil manual in relation to idealism. As defined by cognitive scientists, reality monitoring is a cognitive process by which we can discriminate between real and imagined information (Johnson \& Raye, 1981). When the mechanism of reality discrimination fails, however, one does not know what is real. In a biomedical context, such a failure to discriminate information perceived in the outside world from that which is selfgenerated is termed 'hallucination' (Simons et al., 2017). Furthermore, this lack of discrimination in reality processing can produce experiences of acute vividness:

hallucinations primarily reflect unusually vivid internally generated experiences represented in one or more [...] modality-specific processing areas, experiences that are so vivid that they seem to be external events (Simons et al., 2017, p. 466).

Although we have already noted the vividness and hyper-reality of some of the visualizations in the Qizil fragment, my claim here is not that such meditation is hallucination, but that an impartial consideration of some of the cognitive features of visual hallucination can contribute to this discussion on idealism and visual meditation. To bracket the mental health context for a moment and to reflect only on what is being described cognitively, hallucination can be defined as 'the perception of an object or event (in any of the five senses) in the absence of an external stimulus' (Teeple et al., 2009, p. 26). ${ }^{39}$ An error in reality monitoring occurs when internally generated events are misidentified as being externally existent (Simons, Garrison and Johnson 2017, p. 462). Therefore, clinical definitions of visual hallucination are not pointing to epistemic or ontological idealism but rather to a neurocognitive error (or a sensory misperception). Hence, such definitions are limited in usefulness for understanding meditative visualization, since the 'Qizil Yoga Manual' does not, after all, describe spontaneous events, but rather those that are willed and controlled (a technique).

In what ways, then, might a functional model of visual hallucination be useful in an analysis of this text? One of the key questions for vivid imagery in meditation is: does willful cultivation of such images lead to a breakdown in reality processing (i.e. the ability to discriminate between reality and appearance)? And what would the purpose or outcome of such cognitive disruption be? In their neurocognitive study on reality processing and visual hallucination, Simons et al. (2017) focused on the anterior prefrontal cortex which 'represents records of cognitive operations involved in self-generation, or [...] in self-referential processing or self-representation' (Simons et al., 2017, p. 465). This breaks down into the somato-sensory network (which contains auditory capacity), and, more relevantly, the default mode network, which is responsible for a sense of self. Therefore accuracy in reality monitoring is necessary for self-recognition. Now, this becomes interesting for the 'Qizil Yoga Manual', in which, arguably, the meditation technique is all about self-recognition as represented in the repeated visualized form of self or äśraya. A cognitive

\footnotetext{
39 Hallucination can take place in all sensory modalities, and is not only visual but also auditory, olfactory, tactile, somatic and gustatory (Simons, Garrison and Johnson 2017, p. 466).
} 
disruption to reality processing would appear to produce an alteration in selfrecognition. This is, of course, relevant to the soteriology of the Qizil text because by disrupting what is conventionally real, including one's own bodily subjectivity (seeing the äśraya forming and dissolving in unconventional ways), the goal of the technique is to illustrate what is real in relation to the self. The neurocognitive structure of hallucination, then, can illuminate something about the function and efficacy of these drastically visual meditations called 'yoga', which in their hyperreality seek to produce a new (displaced) understanding of self and world (in accordance with Buddhist doctrines of non-self and impermanence). Vivid visualization in the Qizil dhätuprayoga method is, in a further sense, neither realist nor idealist but about the breakdown between the two. This deliberately unsettling technique was designed to produce profound disruption to everyday cognition with the goal of inducing not only an 'awakening' about the nature of self, but also a transformation therein.

\section{Caves, Murals and the Materiality of Visual Meditation}

In assessing whether this text's worldview can be termed idealist, we have so far considered the role of the body (material subjectivity) and the role of the mind (to generate new mental worlds in visualization). I want to consider a third factor in interpreting this text: the material environment in which the 'Qizil Yoga Manual' was located, specifically the Kucha caves.

Material culture (Miller, 2005) includes the study of embodiment and physicality as well as how bodies interact with material surroundings, but it also challenges subject-object dualism and the idea of representation as indicating superior immaterial forms of lesser material things. As Comeau states: 'New material culture studies provide an approach to religion that centres the material world as the primary condition from which people are motivated to act and a method by which the implied dichotomy of mind and material in South Asian religious studies can be dismantled' (Comeau, 2020, p. 4). Material culture is not just the study of artefacts or things but of ideas and ephemerality too. Miller's account here seems appropriate to the aśraya meditations of the Qizil text:

We cannot comprehend anything, including ourselves, except as a form, a body, a category, even a dream. As such forms develop in their sophistication we are able to see more complex possibilities for ourselves in them [...] We cannot know who we are, or become what we are, except by looking in a material mirror, which is the historical world created by those who lived before us and confronts us as material culture, and that continues to evolve through us (Miller, 2005, p. 8).

In the case of the 'Qizil Yoga Manual' (and other manuals like it), the instructions in the text are only one part of the technique; the other part is the cave as the environment of meditation and as a site often decorated with images of meditation. So let us now add some material detail to our understanding of the method captured in the Qizil fragment - not only were adepts learning from or reading manuals, but 
they were also meditating in caves for long periods, and, furthermore, artists were portraying images and figures related to meditation on cave walls. Here I argue that thinking about the text's meditation as occurring in caves affords us greater confidence in asserting an idealist dimension to the 'Qizil Yoga Manual'.

The cave was a key location for meditation practices in both South Asia and Central Asia. ${ }^{40}$ McMahan (2002) argues for a distinct privileging of the sense of sight over audition in Mahāyāna Buddhist epistemology ${ }^{41}$ and that visual conception is reliant on space (since visual image inherently arises in space) and is atemporal, whereas audition (including audition of language) is inherently temporal. Hence, the cave as a site of 'space' and 'empty space' is a suitable location for visual meditation. The Turfan area (that encompasses Kucha) had many 'meditation caves', structured complexes with a main hall and side chambers (cells) that were most likely used for individual meditation (Yamabe, 2004, p. 401). ${ }^{42}$ At Qizil specifically, there are some 339 caves, ${ }^{43}$ carved into the hillside along a one-mile stretch (Hansen, 2012, p. 68). ${ }^{44}$ The cave construction techniques came from India, 'adopted from the magnificent caves at Ajanta, outside Bombay, and other sites built by early Buddhists' and the murals were '[d]istinctly Indian in style' (Hansen, 2012, p. 69)]. ${ }^{45}$ In the rock temples in Kucha, more than 100 meditation caves are still recognizable, and the ubiquity of meditation cells in particular led Howard and Vignato to conclude 'that meditation was indeed a determining factor in the life of Kucha's monastic communities' (Howard, 2015, p. 20). ${ }^{46}$ In reference to the Toyok Cave 42 in Turfan (5th-7th century) and other Buddhist visualization treatises preserved in Chinese, Yamabe writes: 'Since the structure of the cave itself suggests that these caves were used for meditation, I think it is highly likely that these types of visualization were actually practiced in this cave. Considering that somewhat similar images also appear in the Yogalehrbuch, I think that these rather peculiar images were commonly

\footnotetext{
40 See, for example, Yamabe's discussion of the well-known examples of the Buddha Image Cave in Gandhara (present-day Jalalabad, Afghanistan) (Yamabe 1999a, pp. 263-297).

$41 \mathrm{He}$ argues that this produces a concomitant privileging of vision over language and an ocular-centric epistemic frame that in some ways mirrors western occular-centrism.

42 See Greene for a round-up of recent scholarship on how the textual references to meditation caves 'may not have been the decorated chapel caves, but the smaller, unadorned, cell-like caves that are still found at some sites along the Silk Roads' (Greene 2013, pp. 265-266, fn 1).

43 Howard identifies Qizil Cave 47 'as one of the earliest, datable perhaps to the start of the fifth century' (Howard 2015, p. 20). The caves were closed in 648 CE (Tremblay 2007, p. 98).

44 'Some caves are small, while others range from 36 to 43 feet (11-13m) in height and are 40-60 feet (1218m) deep’ (Hansen 2012, p. 68).

45 For example, Cave 38 at Qizil, dated to $400 \mathrm{CE}$, has an arched ceiling on which is included 'the Indian gods of the sun, moon and wind, as well as two flaming buddhas and a two-headed Garuda, the legendary Indian Buddha who protects Buddhist law' (Hansen 2012, p. 69). Greene suggests that the cave art at Qizil and Toyok is based on the Indian prototype at Tape Shotor (Green 2013, p. 285).

46 Sharf (2013) argues that Central Asian caves such as those in Qizil were mortuary shrines and rarely illuminated. However, Howard disputes this, pointing to the presence of oil and soot in certain caves as evidence that votive lamps were lit frequently and that cave images were hence viewed (Howard 2015, p. 27). Howard also points to the visual depiction of votive lamps in the Qizil Kargha Central Pillar Cave 14 (Howard 2015, p. 27).
} 
visualized by Central Asian meditators' (Yamabe, 2004, p. 465). ${ }^{47}$ The question then becomes: which came first - the text, the mural or the experience of meditation?

Scholars differ as to whether these murals were descriptive or intended as meditative objects and how closely they were tied to texts. There is a distinction between main chambers, in which murals were more commonly found, and individual meditation cells, which were more frequently bare. The dimensions of the meditation cells were compact, with room for just one seated person (Howard, 2015, p. 24) ${ }^{48}$ and they were unadorned with images (Howard, 2015, p. 36). Certainly some murals were not for meditation but were about meditation; in such cases, paintings showed stylised scenes or tableaux of meditation in practice, depicting figures whose heads are tilted to gaze at objects. Such paintings may have had a narrative or veneration function rather than practical (Yamabe, 2004, p. 405). Howard asserts that the images in main halls were not focal points or aids for meditation but were rather 'records of visions and of extraordinary powers derivative from engaging in meditation' (Howard, 2015, p. 25). For Howard, such images allude to or record meditative states, but do not induce them. For Yamabe, however, the connection between image, text and practice is, in some instances, strong: the practitioner first observed a depicted object and then withdrew to a side chamber to meditate upon it (Yamabe, 1999a, p. 458, fn 40). Furthermore, some of the caves in Turfan had murals that appeared to illustrate images from meditation texts. In the side chambers to Toyok Cave $42,{ }^{49}$ for example, there are three paintings of objects for aśubha

\footnotetext{
47 On the cultural currency of the image of the Buddha meditating in a cave, Yamabe notes: 'the motif of the Buddha meditating in Indra's cave was very popular in both Gandhāra and Central Asia' (Yamabe 1999a, p. 336). There is a particular image in the Qizil text that describes a cave in relation to golden mountains and a substance called vaidūrya (variously interpreted to be beryl or a crystal of some sort). The Ganmei sanfo hai jing (Sūtra on the Ocean-Like Samādhi of the Visualization of the Buddha) describes it thus: 'Each color of light becomes a golden mountain, and each mountain has innumerable caves. In each cave one emanation Buddha is seated in the full lotus posture and immersed in deep meditation' (GSHJ T15:663a19-20; trs. Yamabe 1999a, p. 335). For another instance of Śākyamuni Buddha seated in a vaidūrya cave, see GSHJ T15:692c4. In the fragments of the Qizil manual, similar connections of the golden mountain meditation and the cave can be made out: vyutthitasyāpi niṣyamdam anuvartate āśrayam anamtaparyaṃtām sauvarnaguhām. 'Even for [the meditator] who has come out [of the meditation], the after-effect remains; the body, boundless, golden caves...' (YL 130.9; trs. Yamabe 1999a, p. 335). Yamabe seems to be suggesting here that the äśraya is the after-effect. These passages convey some interesting points. Firstly, they suggest details about the design and function of caves: the caves are for meditation, and according to the GSHJ each cave may have a particular emanation Buddha assigned (and hence installed as an icon or image). Secondly, the 'Qizil Yoga Manual' suggests that there is an 'after-effect' to meditation that remains - presumably related to one's own body but perhaps to the visualization of a particular image of the Buddha (if this was indeed the case for the Qizil caves). This is relevant to our understanding of idealism in meditation and whether such effects are temporary or permanent. If this is to be an ontological, specifically soteriological process, how long does the 'after-effect' of meditation last? Following analysis of this visual motif in both the Qizil caves and Gandhara (as well as its presence in various Chinese meditation manuals), Yamabe concludes: 'It would not be too far-fetched to suspect that the popularity of the cave motif in Gandhāra and Central Asia formed the background of the presence of the same motif in the GSHJ and the YL' (Yamabe 1999a, p. 338).

48 ' $[\mathrm{T}]$ hey are shaped with a base just large enough to accommodate a seated person, with the side walls curving to meet an arched soffit. Most of them are single and small-sized, 0.8 to $1 \mathrm{~m}$ deep, 1 to $1.2 \mathrm{~m}$ wide, and 1.2 to $1.5 \mathrm{~m}$ high; they barely contained a seated person, as in the painting from Kizil Cave 171' (Howard 2015, p. 24).

49 Yamabe dates this Toyok cave to mid-fifth-century (Yamabe 1999a, pp. 489-491).
} 
meditation: a skeleton, a naked female corpse and a half-skeletal body (Yamabe, 1999a, pp. 457, 458). At both Toyok ${ }^{50}$ and Qizil ${ }^{51}$ the cave images (both of meditating figures and objects of meditation) are much more likely to be directly related to practices and manuals of meditative visualization, even if the murals are more scattered and disorganized than the texts (Yamabe, 2004, p. 405). ${ }^{52}$ Indeed, Yamabe ventures that the cave murals in the Turfan region as a whole represent a kind of visual language of meditation in the region.

Leaving material images (murals) aside for now, how might the cave itself have structured meditation practice? The Qizil caves suggest immersion for long periods in sensory environments of absence (of light, for instance). ${ }^{53}$ Such conditions may have facilitated the very vividness of the generated imagery in meditation. ${ }^{54}$ Teeple explains that 'visual hallucinations may be induced by prolonged visual deprivation' (Teeple, 2009, p. 27). Moreover, Simons et al. add: '[h]allucinations are sometimes experienced spontaneously in healthy individuals during periods of sensory deprivation' and 'hyperactivation of sensory processing cortices might provide the perceptual content for hallucinatory experiences' (Simons et al., 2017, p. 469). Another potential feature of prolonged periods of meditation is tiredness, an additional factor that can induce error in an 'otherwise intact reality monitoring system', so that subjects experience a 'sporadic hallucination' (Simons et al., 2017, p. 470). ${ }^{55}$

This brief discussion has demonstrated that the materiality of the cave is a necessary context for interpreting the visual methods of the 'Qizil Yoga Manual'. This context supports our understanding of how vivid visualization in a meditation cave could be designed to disrupt the cognitive function called reality monitoring:

Reality monitoring processes are fundamental for maintaining an understanding of the self as a distinct, conscious agent interacting with the world, perceiving and interpreting external information relating to events happening around us and generating our own thoughts and imagination and responses (Simons et al., 2017, p. 470).

\footnotetext{
${ }^{50}$ One image depicted in the Toyok caves and also described in the Qizil Fragment (as well as in Chinese meditation manuals) is that of the burning lotus pond and the boy emerging from a lotus (Yamabe 1999a, pp. 332-334).

${ }^{51}$ Drawing on the work of Sūdo and others, Yamabe summarises that the cave paintings at Qizil have a different character to those at nearby sites such as Toyok. Whereas in the Toyok caves 20 and 42 'scenes of visualization are lined up horizontally and seem to presuppose detailed visualization manuals', the Qizil paintings are 'scattered in natural sceneries and are painted in a very unstylized way' (Yamabe 1999a, p. 429).

52 At Toyok, however, the design of the murals reflects efforts at 'systematization on the part of local meditators' (Yamabe 2004, p. 405).

53 See footnote 46 .

${ }^{54}$ It will be interesting to monitor emerging research in cognitive science on cave dwelling such as that carried out by the Deep Time project to study participants who lived in a cave setting for 40 days and nights in order to assess how the brain is impacted by such environmental conditions. See https://deeptime. $\mathrm{fr} / \mathrm{en} /$ [last accessed 22.05.2021]

55 On tiredness and hallucination, see also Teeple et al., 2009, p. 27. On the similarity of some waking hallucination to dreaming sleep stages see Gottesmann 2005.
} 
It is precisely this stable self (and the stable subject/object divide) that the Qizil manual seeks to disrupt in its soteriology of awakening. In a cave of sensory deprivation how could the ontology, soteriology, or indeed epistemology, be anything but idealist - in the immediacy and deep absorption of that secluded (and possibly dark) environment, there was little left of a perceptibly external world, apart from the one generated in meditative visualization.

\section{Willed, non-willed and cultivated visualization}

There is still ambiguity over the question of whether visualizations were entirely willed or in part spontaneous. This raises an important point about two different types of visualized image in Chinese meditation manuals such as the Secret Essential Methods of Meditation - there are not only constructed images but also 'confirmatory visions' which arise involuntarily without forewarning to signal that the adept has achieved a particular attainment (Greene, 2016b, p. 319). ${ }^{56}$ However, the chances of identical, non-willed (i.e. spontaneous) images arising in more than one practitioner is unlikely and we know that monks were expected to cultivate the same images, as evidenced by the shared materials (texts or murals). Indeed, the evidence suggests that individuals (in conditions of sensory deprivation) might be able to generate remarkably similar imagery according to prior training (such as recollection techniques), while any involuntary visual hallucinations would be highly idiosyncratic. Quite how involuntary visions could have operated across a group to signify progress is not easy to understand (i.e. that many monks would spontaneously see vividly detailed images, such as those in our Qizil text). Greene explores the possibilities that some images are not meditative but part of divination, including oniromancy or dream-divination (Greene, 2016b, pp. 322, 323), but it appears that further investigation and explanation is required here.

\section{Collective minds, intersubjective meditation and solipsism}

How might the cave art itself be an attempt to represent the feedback loop of meditation: both by providing objective visual prompts for internal imagery and by exteriorizing images (by artistically materializing them) from the internal subjective meditation process (i.e. recording them)? In this sense the wall paintings might not be an aide-mémoire ${ }^{57}$ but a visual record of collective meditating minds. It is unclear to what extent these cave meditations generated solipsistic realities, ones that could not be perceived by another monk. Yet, as Howard shows, individual cells were not the only type of meditation caves; she points to the existence of larger 'collective meditation caves' 58 that could be 'used simultaneously by several monks' (Howard, 2015 , p. 24). The Turfan texts, caves and murals suggest shared visual experiences

\footnotetext{
56 See also discussion in footnote 35 .

57 It is not clear what the relationship might have been between listening, seeing, and reading in absorbing the contents of the meditation method. One point to consider is how the Qizil manual was transmitted was it recited orally for instruction? If so, could groups of monks have been instructed at the same time in a single cave complex - all hearing the same words but having slightly different visualizations?

58 She cites the example of Tograk-eken in Kucha.
} 
and intersubjective meditation rather than solipsistic. ${ }^{59}$ My speculation here is that this meditative method of Qizil, originally structured by South Asian Buddhist meditation texts, took on an especial and local quality in the caves of Kucha, determined by a specific feedback loop between practices of meditation and murals thereof. The 'Qizil Yoga Manual' is an attempt to record this process, perhaps written down at a time when monks had to depart from the caves for short or long periods.

\section{Conclusions}

The visualizations in the 'Qizil Yoga Manual' reflect an intense viscerality rooted in bodily subjectivity and sensori-motor experience. Hence this paper has considered meditation by using perspectives from material culture that focus on both embodiment and environment. The paper has also discussed cognitive features of visual hallucination, such as the breakdown in reality processing, as a lens through which to review subjective idealism, the assertion that objects of perception can be mind-dependent. Arguably, the Qizil techniques may share some cognitive features or structures with 'willed' or 'induced' hallucinations in that they disrupt everyday reality processing and replace it with an alternative ontology, designed to reveal deeper truths about reality and non-self in accordance with Buddhist doctrine. What is the effect of this temporary soteriological idealism and how long does the 'aftereffect' last? ${ }^{60}$ As Dragonetti points out, what is happening in willed visualization is twofold: the mind is both generative and cessative in meditation, expressing the power 'to visualize objects at will and to suppress the surrounding reality and the contents of the mind, leaving the mind empty and isolated' (Dragonetti, 2000, p. 173). This meditation method is idealist in that it engenders (and is engendered by) a temporary environmental condition, cultivated to attain liberation. For the yogin in the cave, it does not matter whether the external world continues or not, is independent or not; all that matters in this method is the method itself - its process and outcomes for subjectivity (i.e. a theory and a practice of the self). The caves as sites of sensory deprivation are also sites for generating new worlds, albeit temporary. In Paving the Great Way, Gold rejects solipsistic idealism in Vasubandhu's work in favour of 'Buddhist Causal Framing [which] places sensible conditions on the kinds of affirmation such a reality permits' (Gold, 2014, pp. 223224). But in our text, the 'Qizil Yoga Manual', what is affirmed as external reality is not constrained by the more mainstream 'Buddhist Causal Framing' ${ }^{61}$ Indeed, it is

\footnotetext{
59 Similarly, in reference to the Chan miyao jing (Secret Essential Methods of Meditation) (c. 5th century), Greene points out: 'the objects seen by the meditator are said to be composed of the four material elements $[\ldots]$ and are said to become visible to others under certain circumstances [...] Similarly, though the visions are sometimes dismissed as somehow unreal, this is because they are dependently originated just as is the material body' [author's original emphasis] (Greene 2016b, p. 327). Indeed in his analysis of avijnaptikarma and avijñapti-rüpa, Greene summarises the dispute between Vasubandhu and Sanghabhadra on the issue of visibility of certain objects in meditation and points out that there are specific terms used to describe samädhi objects that are imagined or magically generated: vikalpa (imagination), parikalpa (parikalpita or imagined) and adhimokșa (resolve) (Greene 2016a, p. 132).

60 See footnote 47.

61 See Lusthaus 2002, especially Chapter 5, for a rejection of Yogācāra epistemology as solipsistic.
} 
tempting here to posit Trivedi's definition of solipsism: 'some metaphysical idealists [...] are extreme subjective idealists and claim that the only thing that exists is me, my mind and ideas and things in it' (Trivedi, 2005, p. 232). Yet this is not to assert that the Qizil cave meditators should be labelled as solipsists, and we have discussed how this meditation community appeared to operate intersubjectively. Perhaps, then, Lusthaus's evaluative label 'cognitive narcissism' fits better to describe the áśraya visualizations (Lusthaus, 2002, p. 540). Ultimately, the adept learns that the paramount imagined object is, of course, the self. Even though Wayman's foundational article 'A Defence of Yogācāra Buddhism' strongly positions Yogācāra as not idealist (on the grounds that representation-only points to cognitive errors that can be remedied), ${ }^{62}$ he nonetheless highlights the key role for subjectivity in relation to truth:

Of course, the Yogācāra put its trust in the subjective search for truth by way of a samādhi. This rendered the external world not less real, but less valuable as a way of finding truth (Wayman, 1996, p. 470).

What is at stake in the Qizil method is subjectivity itself and its nature, not the objective world. Hence the cave provided the ideal material conditions for a practical, soteriological idealism (to attain liberation) rather than an absolute metaphysical theory.

Acknowledgements Thank you to the organisers for an invitation to attend the "Yogalehrbuch" Reading Retreat, 2019' part of the Yogalehrbuch Translation Project, 'An English Translation of a "Buddhist Yoga Manual" from Kuca', Ludwig-Maximilians-Universität, 26-31 August. Thank you also for feedback received when I presented an earlier version of this paper at the 2020 American Academy of Religion Annual Meeting, as part of the panel 'Yogācāra as Idealism? The State of the Debate and New Avenues of Inquiry', organised by the Yogācāra Studies Unit.

\section{Declarations}

Conflict of interest The author states that there is no conflict of interest.

Open Access This article is licensed under a Creative Commons Attribution 4.0 International License, which permits use, sharing, adaptation, distribution and reproduction in any medium or format, as long as you give appropriate credit to the original author(s) and the source, provide a link to the Creative Commons licence, and indicate if changes were made. The images or other third party material in this article are included in the article's Creative Commons licence, unless indicated otherwise in a credit line to the material. If material is not included in the article's Creative Commons licence and your intended use is not permitted by statutory regulation or exceeds the permitted use, you will need to obtain permission directly from the copyright holder. To view a copy of this licence, visit http://creativecommons.org/licenses/by/4.0/.

\footnotetext{
62 '...these causes of error are not the theory that the world is an illusion, since they are causes of error that can be "seen through", appreciated for what they are, in particular' (Wayman 1996, p. 469).
} 


\section{Abbreviations}

$\begin{array}{ll}\text { AKBh } & \text { Abhidharmakośabhāṣya } \\ \text { GSHJ } & \text { Ganmei sanfo hai jing } \\ \text { MMPS } & \text { Mahāyāna Mahāparinirvānasūtra } \\ \text { PYŚ } & \text { Pātañjalayogaśāstra } \\ \text { Yv } & \text { Yogavidhi } \\ \text { YL } & \text { Yogalehrbuch }\end{array}$

\section{References}

Anacker, S. (1984). Seven works of Vasubandhu, the Buddhist psychological doctor. Delhi: Motilal Banarsidass.

Bayer, A., et al. (2019). The world arises from mind only: Candrakīrti's affirmation of cittamātra at madhyamakāvatāra 6.87. In V. Caumanns (Ed.), Unearthing himalyan treasures: Festschrift for Franz-Karl Erhard. Marburg: Indica et Tibetica.

Bretfeld, S. (2003). Visuelle repräsentation im sogenannten "Buddhistischen Yogalehrbuch" aus Qizil. In S. Bretfeld \& J. Wilkins (Eds.), Indien und zentralasien sprach- und kulturkontakt. Wiesbaden: Harrasowitz.

Buescher, H. (2008). The inception of Yogācāra-Vijñānavāda. Verlag der Österreichischen Akademie der Wissenschaften.

Comeau, L. (2020). Material devotion in a South Indian poetic world. Bloomsbury studies in material religion. London: Bloomsbury Academic.

Davidson, R. (2010). The place of abhișeka visualization in the Yogalehrbuch. In E. Franco \& M. Zin (Eds.), From Turfan to Ajanta: Festschrift for Dieter Schlingloff on the occasion of his eightieth birthday. Rupandehi: Lumbini International Research Institute.

Deleanu, F. (Ed.). (2006). The chapter on the Mundane Path (Laukikamārga): A trilingual edition (Sanskrit, Tibetan, Chinese), annotated translation and introductory study (2 vol). Tokyo: International Institute for Buddhist Studies.

Demiéville, P. (1951). La Yogācārabhūmi de Saṅgharakṣa. Bulletin Du L'école Française D'extrêmeOrient, XLIV, 339-436.

Dragonetti, C. (2000). Marginal note on the idealistic conception of Citta-Mātra. Journal of the International Association of Buddhist Studies, 23(2), 165-175.

Dunne, J. (2004). Foundations of Dharmakirti's philosophy. Studies in Indian and Tibetan Buddhism. Boston: Wisdom.

Garfield, J. (2002). Empty words. Buddhist philosophy and cross-cultural interpretation. Oxford: Oxford University Press.

Gold, J. (2007). Yogācāra strategies against realism: Appearances (ākṛti) and metaphors (upacāra). Religion Compass, 1(1), 131-147.

Gold, J. (2014). Paving the great way: Vasubandhu's unifying philosophy. New York: Columbia University Press.

Gottesmann, C. (2005). Waking hallucinations could correspond to a mild form of dreaming sleep stage hallucinatory activity. Behavioral and Brain Sciences., 28(6), 766-767.

Greene, E. (2013). Death in a cave: Meditation, deathbed ritual, and skeletal imagery at tape shotor. Artibus Asiae, 73(2), 265-294.

Greene, E. (2016a). Seeing Avnijñapti-rūpa - Buddhist doctrine and meditative experience in India and China. In K.-P. Chuang (Ed.), Buddhist meditative traditions: Comparison and dialog (Fo jiao chan xiu chuan tong: bi jiao yu dui hua) (pp. 107-170). Taipei: Dharma Drum Publishing Corporation.

Greene, E. (2016b). Visions and visualizations: In fifth-century China and 19th-century experimental psychology. History of Religions, 55(3), 289-328.

Greene, E. (2018a). Religion of images?-Buddhist image worship in the early medieval Chinese imagination. Journal of the American Oriental Society, 132, 2. 
Greene, E. (2018b). The scripture on the secret essentials of meditation: The authority of meditation in the kaiyuan era. In M. Bemmann \& S. Hua (Eds.), Buddhist stone sutras in China: Sichuan Province 4 (pp. 75-92). Wiesbaden: Harrassowitz.

Hansen, V. (2012). The silk road: A new history. Oxford: Oxford University Press.

Hartmann, J. (2004). Buddhism along the silk road: On the relationship between the Buddhist sanskrit texts from Northern Turkestan and those from Afghanistan. In: Durkin-Meisterenst, D. (Ed.), Turfan revisited - The first century of research into the arts and cultures of the silk road. Monographien zur indischen Aachäologie, kunst und philologie; Bd. 17. Berlin: Reimer. S. 125-128.

Hartmann, J. (2006). Neue fragmente as dem Yogalehrbuch. In D. Schlingloff, J. U. Hartmann, \& H. J. Röllicke (Eds.), Ein Buddhistisches Yogalehrbuch: Unveränderter Ausgabe von 1964 unter Beigabe Aller Seither Bekannt Gewordenen Fragmente. Dusseldorf: EKO Haus der Japanischen Kulture.

Howard, A. (2015). On "Art in the Dark" and meditation in Central Asian Buddhist caves. The Eastern Buddhist., 46(2), 19-40.

Howard, A., \& Vignato, G. (2015). Archaeological and visual sources of meditation in the Ancient Kingdom of Kuča. Brill: Leiden.

Kochumutton, T. (1982). A Buddhist doctrine of experience: A new translation and interpretation of the works of Vasubandhu the Yogācārin. Delhi: Motilal Banarsidass.

Johnson, M. K., \& Raye, C. L. (1981). Reality monitoring. Psychological Review, 88, 67-85.

Lamotte, E. (1935). Saṃdhinirmocana Sūtra: L'Explication des Mysteres. Librairie d'Amérique et D'Orient.

Lusthaus, D. (2002). Buddhist phenomenology: A philosophical investigation of Yogacara Buddhism and the Ch'eng Wei-Shih Lun. Curzon critical studies in Buddhism series. London: Routledge.

McMahan, D. (2002). Empty vision: Metaphor and visionary imagery in Mahāyāna Buddhism. London: RoutledgeCurzon.

Miller, D., et al. (2005). Materiality: An introduction. In L. Meskell (Ed.), Materiality. Durham: Duke University Press.

Nagao, G. (1991). Connotations of the word Āśraya (Basis) in the Mahāyānasūtrālamkara. In Mādhyamika and Yogācāra: A study of Mahāyāna philosophies. Collected papers of GM Nagao. Delhi: Sri Satguru, Indian Books Centre (Bibliotheca Indo-Buddhica 105).

O’Brien-Kop, K. (2018). Classical discourses of liberation: Shared botanical metaphors in Sarvāstivāda Buddhism and the Yoga of Patañjali. Religions of South Asia, 11(2-3), 123-157.

O'Brien-Kop, K. (2020). Dharmamegha: The revision of a superlative metaphor. Journal of Indian Philosophy, 48, 4.

O’Brien-Kop, K. (2021). Rethinking “classical yoga' and Buddhism: Meditation metaphors and materiality. Bloomsbury Advances in Religious Studies Series. Bloomsbury Academic: London

Rahder, J. (Ed.). (1926). Daśabhūmikasūtra. Leuven: JB Istas.

Ratié, I. (2010). The dreamer and the yogin: On the relation between Buddhist and Saiva idealisms. Bulletin of SOAS, 73(3), 437-478.

Rotem, O. (1993). Vasubandhu's idealism: An encounter between philosophy and religion. Asian Philosophy, 3, 15-28.

Schlingloff, D. (1964). Yogavidhi. Indo-Iranian Journal, 7(2/3), 146-155.

Schlingloff, D. (1966). Ein Buddhistisches Yogalehrbuch. Sanskrittexte aus den Turfanfunden VIIa. Akademie: Berlin.

Schlingloff, D. (2006). Ein Buddhistisches Yogalehrbuch: Unveränderter Ausgabe von 1964 unter Beigabe Aller Seither Bekannt Gewordenen Fragmente. Ed. Hartmann, JU, and Röllicke, HJ. Dusseldorf: EKO, Haus der Japanischen Kulture

Schmithausen, L. (1973). Spiritual practice and philosophical theory in Buddhism. In German scholars on India: Contributions to Indian Studies. Varanasi: Chowkhamba Sanskrit Series Office.

Seyfort Ruegg, D. (1967). On a Yoga fragment from Qïzïl. Journal of the American Oriental Society, 87, $157-165$.

Simons, J. S., Garrison, J. R., \& Johnson, M. K. (2017). Brain mechanisms of reality monitoring. Trends in Cognitive Sciences, 21(6), 462-473.

Stuart, D. (2015). A Less travelled path: Saddharmasmrtyupasthānasūtra Chapter 2: Critically edited with a study on its structure and significance for the development of Buddhist meditation, Volumes 1 and 2. Beijing: China Tibetology Publishing House and Austrian Academy of Sciences Press.

Teeple, R., et al. (2009). Visual hallucination: Differential diagnosis and treatment. In Primary care companion Journal of Clinical Psychiatry 11.1. 
Tremblay, X. (2007). The spread of buddhism in Serindia: Buddhism among Iranians, Tocharians and Turks before the 13th century. In A. Heirman and S. Bumbacher (Eds.) The spread of Buddhism. Leiden: Brill.

Trivedi, S. (2005). Idealism and Yogacara Buddhism. Asian Philosophy, 15(3), 231-246.

Wayman, A. (1996). A defence of Yogācāra Buddhism. In: Philosophy East and West. 46.4.447-476.

Willis, J. (1979). On knowing reality: The Tattvārtha chapter of Asañga's Bodhisattvabhümi. New York: Columbia University Press.

Yamabe, N. 1999a. 'The Sūtra on the ocean-like Samādhi of the visualization of the Buddha: The Interfusion of the Chinese and Indian Cultures in Central Asia as Reflected in a Fifth Century Apochrypal Sūtra'. Yale: PhD Dissertation.

Yamabe, N. 1999b. The significance of the "Yogalehrbuch." In: Buddhist Culture 9.

Yamabe, N., et al. (2004). An examination of the mural paintings by visualising monks in Toyok Cave 42. In D. Durkin-Meisterernst (Ed.), Conjunction with the origin of some Chinese texts on meditation' in Turfan Revisited: The first century of research into the arts and cultures of the silk road. Berlin: Dietrich Reimer.

Yamabe, N. (2006). Fragments of the Yogalehrbuch in the Pelliot collection. In J. U. Hartmann \& H. J. Röllicke (Eds.), Ein Buddhistisches Yogalehrbuch: Unveränderter Ausgabe von 1964 unter Beigabe Aller Seither Bekannt Gewordenen Fragmente (pp. 325-341). EKO, Haus der Japanischen Kulture: Dusseldorf.

Publisher's Note Springer Nature remains neutral with regard to jurisdictional claims in published maps and institutional affiliations. 